\title{
有限要素法による矩形板の 2 次座屈解析* \\ A Seconddary Buckling Analysis of a Rectangular Plate \\ by the Jeinite Element Method
}

平田隆教**

Takamori Hirata

\begin{abstract}
The purpose of this paper is to describe the secondary buckling analysis of rectangular plates under axial compression by the finite element method. This method, which is proposed by the author et al., is a kind of lagragian formulation, and is very convenient for the nonlinear analysis of beams and plates.

In this paper, as typical examples of this method, the results of uniformly compressed square plates with four types of boundary conditions is presented. In detail, the post-buckling path of the square plates is calculated, and also the secondary buckling value and the deformation mode are caluculated, which is obtained when the deformation after the buckling becomes large and unstable again.

Finally, this method is available for the analysis of rectangular plates with initial imperfection or reinforced members, but is not used for such cases in this paper because of the shortage of page.
\end{abstract}

\section{1.はしがき}

1 軸圧縮荷重を受ける矩形板は，1 次座届後も耐荷 能力を持つことが SCHUMANN ${ }^{12}$ らの実験, あるいは SCHNADEL ${ }^{22}$ の理論計算により明らかとなり，KÁRMÁN ${ }^{3)}$ らによる有効幅の理論加生まれた。 その後,

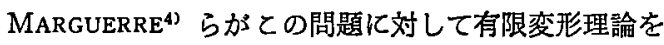
適用し，エネルギー法を用いて近似計算したのに端を 発し，数多くの研究(5) -8) がなされているまた最近で は，矩形板は 1 次座届後む耐荷能力をすつが，荷重の 増加とと毛酒び不安定となり, さらに高次の波形へ 亡座屈する現象 (2次座屈) が注目され, STEIN ${ }^{9)} に$ より棒とバネ系のモデルで解析された，その後，エネ ルギー水準を考え，2次座屆前後の基準波形亡高次波 形とで等しくなる軸压縮応力值が存在することから， 2 次座屈現象の可能性を説明した近藤, 林の研究 ${ }^{102}$, 全ポテンシャル・エネルギーの第 2 変分による植村の

* 昭和 50 年 11 月 7 日日本航空宇宙学会西部支部において 講演, 昭和 51 年 5 月 20 日原稿受理

** 東洋工業株式会社
方法 ${ }^{11)}$ 用いて，2 次座屆の必然性を座届後の平衡状 態の安定判別から解析した植村，辺の研究122がある. さらに微小挸乱波形を多数項で表わし，初期撓みの影 響をも含めて解析し，実験結果と比較した辺，植村の 研究 ${ }^{13)}$ あある. その他 1 軸圧縮以外の場合では，フラ ッター解析から2 次座屈現象の必然性を説明した小林

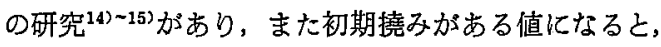
2 次座届の起こりうるととを説明した SUPPLE の研 究 ${ }^{16)}$ ある.

さて，本論文では筆者らの提案した ${ }^{172199}$ 有限要素 法による方法を用いて，矩形板の 2 次座屈現象につい て検討を行うこととするが，その特色は次の 4 つ，す なわち,

（1）従来の解析的研究では，微小掜乱波形の与え 方に限界があり, 必ずしも最小の 2 次座屈值が求 められないか゚，本論文の方法ではとの点が大幅に 改良される。

（2）境界条件が複雑な場合であ適用できる.

（3）初期撓み，および補強材がある場合も極めて 簡单である。

（4） 2 次座屆後の平衡状態皇求められる. にある.

\section{2. 矩形板の 1 次座屈後の様相と 2 次座屈現象}

ここでは, 1 軸圧縮荷重を受ける矩形板の 1 次座届 後の平衡曲線を求めるとともに，座屈後の変形がかな り大きくなると再び不安定となり，2 次座届現象が起 こることについて述へる，との場合，境界条件亡して は次の 4 つ,すなわち,

(a) 周辺が固定であり，面内境界条件としては,

断面力 $N_{y y}$ が $y=b / 2,-b / 2$ で

$N_{y y}=0$ の場合（第 1 図）.

（b）周辺が固定であり，面内境界条件としては $y$ 方向の変位 $v_{y}$ が $y=b / 2,-b / 2$ で $v_{y}=0$ の場 合.

（c）周辺が単純支持で，面内境界条件が（a）の場 合.

（b）周辺が単純支持で，面内境界条件が（b)の場 


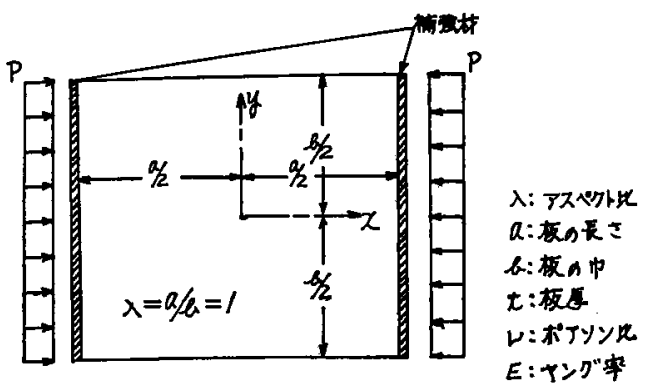

第 1 図 1 軸正縮荷重を受ける矩形板 (周辺が固定で面 内境界条件か $N_{y y}=0$ の場合)

合.

とし, 断面力 $N_{x y}$ は (a), (b), (c)，(d) ともに $x=a / 2,-a / 2$, および $y=b / 2,-b / 2$ で $N_{x y}=0$ 之 する。

また，荷重条件としては，荷重忍の変位が一定の条 件を用いることとする.

なお，板要素の分割数としては， 1 次座届值の精度 之計算時間を考慮して，16×16 分割とするか， 1 次座 屈波形，および 2 次座屈波形が $y$ 方向には対称性を有 するため，上半分で計算を行った。

2.11 次座屈後の平臭曲線 ここでは，前述した 各種の境界条件 (( a ), (b), (c), (d)) の下での 1 次 座屈後の平衡曲線，および撓み波形の変化，断面力の 変化等について述べ. この場合, 荷重の無次元量と しては, 平均軸応力 $\sigma=(P / b t)$ を無次元化した

$$
\bar{\sigma}=\sigma / \sigma e
$$

を用いるとととする.ここで $\sigma_{e}$ は，

$$
\sigma_{e}=E \pi^{2} t^{2} / 12\left(1-\nu^{2}\right) b^{2}
$$

である. また，变位 $(w)$ の無次元量としては, $\bar{w}=w / t$

を用いるとととする。なお，あ。 は中央点の変位の無 次元量を表わす.

(a)の場合 周辺が固定で, 面内境界条件が $N_{v y}$ $=0$ の場合には, 1 次座屈值（第 2 図の・囵） $\bar{\sigma}_{c r}$ か $\bar{\sigma}_{\text {er }}=9.62$

となり，座屈後の平衡曲線は第 2 因の ( a ) 如〈求めら れた. また，第2因の(1)，(2)，(3)点での中央断面（ $=0$ ，および $y=0)$ 上の撓み波形の変化が第 3 図に， $x=0,-a / 4,-a / 2$ での断面力 $\left(\bar{N}_{x x}=N_{x x} / \sigma_{e} t\right)$ の変 化が第 4 図に示されている.

（b）の場合 周辺が固定で，面内境界条件が $v_{y}=0$ の場合には, 1 次座屈值 $\bar{\sigma}_{e r}$ 名

$$
\bar{\sigma}_{c r}=7.9
$$

となり，座届後の平衡曲線は第 2 図の(b)の如くなっ た. またこの場合には，第 2 困の平衡曲線 (a), (b) が接近しているてとから分加る如く，撓み波形の変

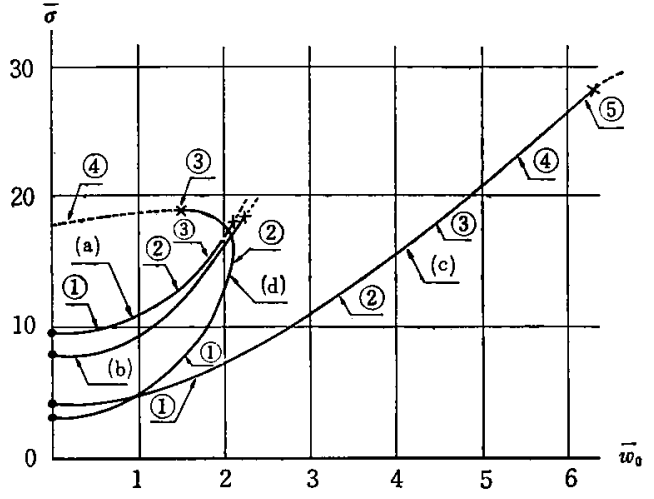

第 2 図 1 次座届後の平衡曲線
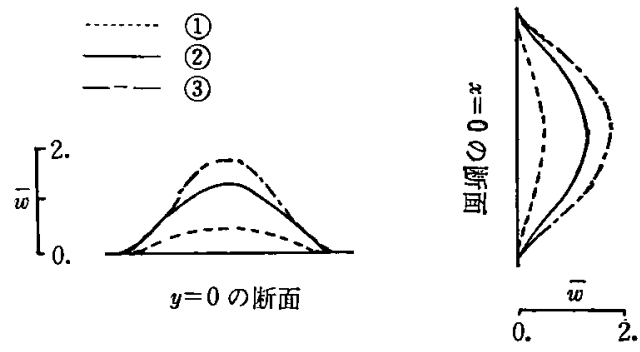

第 3 図 撓み波形の変化（(a)の場合）

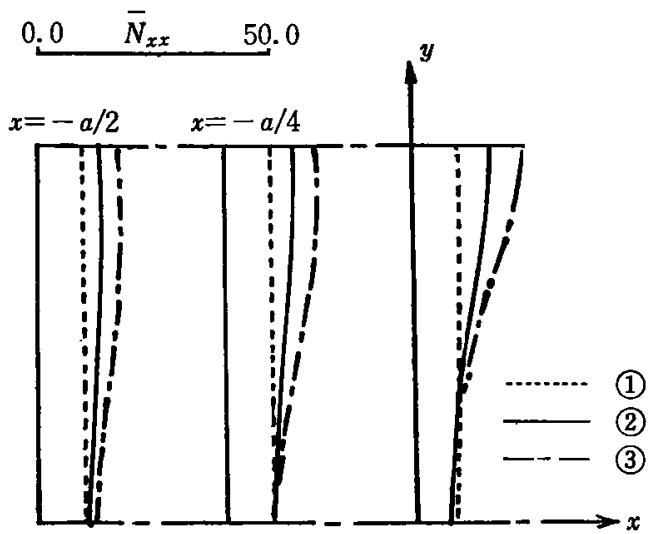

第 4 図 断面力の変化 ((a)の場合)

化，および断面力の変化は前述した第 3 図，および第 4 図とほとんぞ同樣であった.

(c)の場合 周辺が単純支持で, 面内境界条件が $N_{y y}=0$ の場合には, 1 次座届值 $\bar{\sigma}_{c r}$ が

$$
\bar{\sigma}_{c r}=3.96
$$

となり，座屈後の平衡曲線は第 2 困の（c）の如くなっ た。また，第 2 図の(1)，(2)，(3)，(4)，(5)点での中央断 面の撓み波形の変化が第 5 四に，断面力の変化が第 6 図に示されている，乙の場合には，捁み波形および断 面力の変化ともに，(a), (b)の場合と著しく異なり， 座屈後にかなりの大変形を起とすとととなった。 

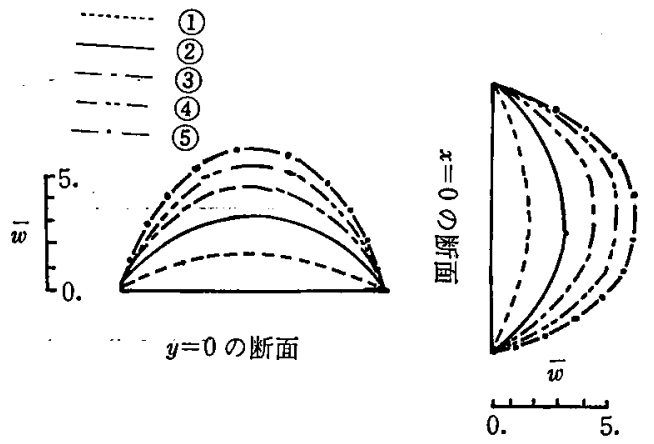

第 5 図 撓み波形の変化 ((c)の場合)

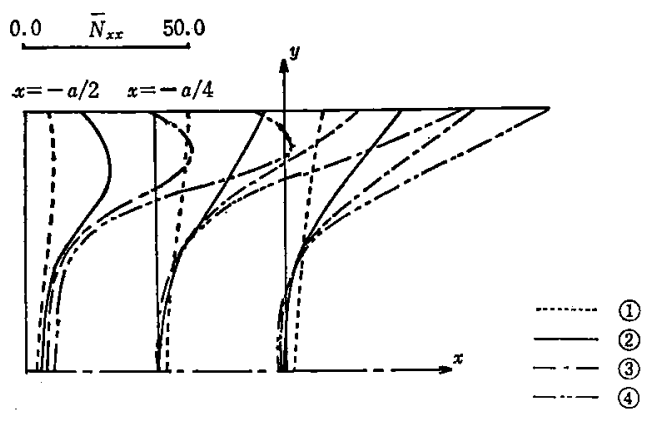

第 6 図 断面力の変化 ( (c)の場合)
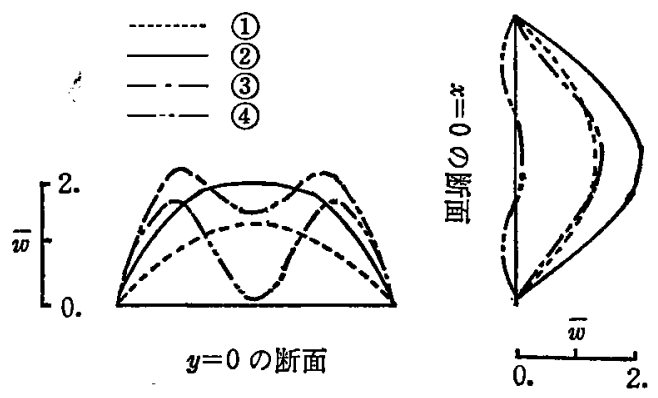

・第7四堯み波形の変化 ((d)の場合)

（d）場合 周辺が単純支持で，面内境界条件が $v_{y}=0$ の場合には, 1 次座屈值 $\widetilde{\sigma}_{c r}$ が

$$
\vec{\sigma}_{c r}=3.09
$$

となり，座届後の平衡曲線は第 2 図の(d)の如くなっ た. また，第 2 図の(1)，(2)，(3)，(4)点での中央断面上 の撓み波形の変化は第7図の如くなり，(a)，(b)， （c）の場合とは著しく異なる結果となった. しかし， 断面力の変化は (c)の場合之同様の結果が得られた.

2.22 次座屈值と座屈波形 第 2 図に示された 1 次座届後の平衡曲線は安定であるが, 変形が大きくな ると， $\bar{D}$ おび $\bar{D}^{*}$ (全剛性マトリックスの Determinant) が減少し(第 8 図)， $\bar{D}=\bar{D}^{*}=0$ となると再 び不安定となり，2 次座届を起とすとととなる。

各種境界条件での 2 次座屈值 $\sigma_{c r}$ (第 2 図の $\times$ 时)

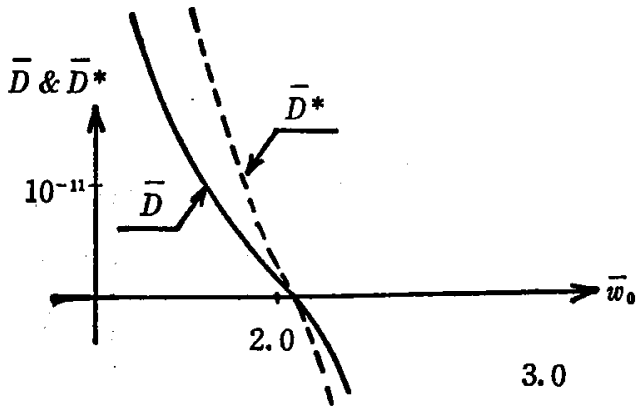

第 8 図 $\bar{D} \& \bar{D}^{*}$ の変化 $\left(N_{y y}=0\right.$ の場合 $)$
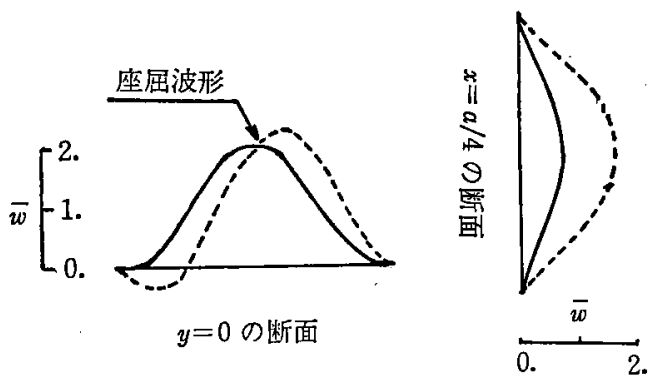

第9図 2 次座届波形（(a)の場合）

第 1 表 2 次座届値之座屈波形

\begin{tabular}{|c|c|c|}
\hline 面内条件 & 固 定 & 単 純 支 持 \\
\hline$N_{y y}=0$ & ( 2 半波 1 半波) & $\left(\begin{array}{c}\left.x, y \text { 方向共 } 3 \text { 半波と }{ }^{1}\right) \\
\left.\text { 半波の重瞢した波形 }^{2}\right)\end{array}\right.$ \\
\hline$v_{y}=0$ & $\begin{array}{c}17.8 \\
(2 \text { 半波 } 1 \text { 半波) }\end{array}$ & $\begin{array}{c}18.8 \\
\text { (同 }{ }^{2} \text { 上) }\end{array}$ \\
\hline
\end{tabular}

および座屈波形（第 9 図，第 10 図の破線）が第 1 表 に示されている。

なお，(d)の場合には $\bar{D}=0$ となるが， $\bar{D}^{*} \neq 0$ と なり (a)，(b)，(c)の場合の如く分岐座屈タイプでは なく，飛び移り座届タイプの 2 次座届現象を呈した.

計算結果の検討 周辺が固定の場合には, 面内境界 条件が $N_{y y}=0$ (a)， $v_{y}=0$ (b) の場合ともに，2半 波 1 半波の典型的な 2 次座届を起こした (第 9 図).11

また， 2 次座屈値は $v_{v}=0$ の場合が少し高くなり， 1 次座届値とは全く逆の結果となったが，とれは、 $=0$ の場合には 2 軸压縮荷重が作用することとなり， 1 半波 1 半波（1 次座屈波形）蛙起こり易いか， 2 半 波 1 半波（2 次座屆波形）、起とりにくくなるためと 思われる.

周辺が単純支持の場合は，面内境界条件が $N_{v v}=0$ (c), $v_{y}=0$ (d) の場合とむに, 3 半波と 1 半波の重 量波形の 2 次座届を起とした（第 10 図）.

また，2 次座届値は周辺固定の場合に比へて高くな り，1 次座屈値とは全く逆の結果となったが，これは 

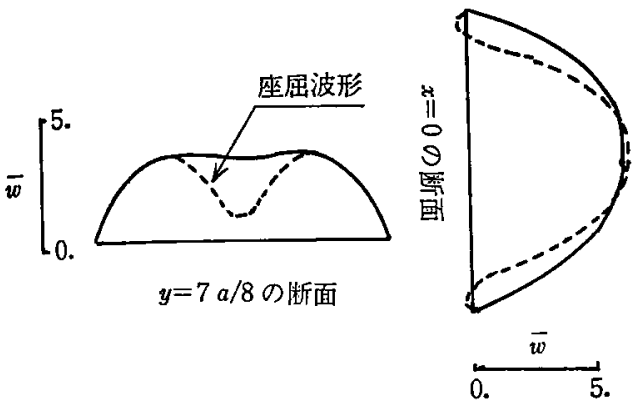

第 10 図 2 次座届波形 ( ( c ) の場合)

周辺が単純支持の場合には，1半波 1 半波は起こり易 いが，座屈後の大撓み変形状態での曲げ変形む大きく なるため，周辺が固定の場合の如く 2 半波 1 半波とは なりにくく, より高次の 3 半波と 1 半波の重量波形で 2 次座屈を起とすためと思われる。

周辺が単純支持の場合には， $N_{y y}=0$ の場合の方が $v_{y}=0$ の場合より 2 次座屈值が高くなったが，てれは 1 次座屈值の場合之同様であり， $v_{y}=0$ の場合には 2 朝王縮荷重を受けるため， 1 半波 1 半波，および 3 半 波と I半波の重量波形共に起こり易くなるすのと思わ れる。

また，周辺が単純支持で， $v_{y}=0$ の場合(d)には， (a)，(b)，(c) の場合之は全く異なり，分岐座屈夕イ プではなく飛び移り座屈タイプの 2 次座屈現象を呈し たが，乙九は， 3 半波と 1 半波の重量波形が極的て起 こり易いために，わずかの計算誤差からくる撜乱撓み により，分岐座屈現象が起こらず，飛び移り現象にな るあのか，あるいはまた，理論的な現象であるかにつ いてはまだ明らかではなく，さらに詳細な研究が必要 と思われる. との点については続報で述べる初期撓み を有する矩形板の 2 次座屈現象についての研究で明ら かとしたい.

\section{3. 結 ひ}

本論文では有限要素法を用いて，矩形板の 1 次座届 後の平衡曲線を求めるとともに，座屈後の变形がかな り大きくなると再び不安定となり，2 次座屈現象を起 てすととが分かった。

また，本論文の方法では，境界条件の複雅な場合， あるいは初期撓み，および補強材のある場合にあ，容
易に適用でき，良好な結果が得ら机たがここでは割爱 した.

終わりに臨み，本研究の御指導をいただいた東大宇 宙航空研究所，植村益次教授に厚く感謝の意を表する 次第である.

\section{参考 文 献}

1) L. Schumann and G. Back: Strength of Rectangular Flat plates under Edge Compression, NACA TR No. 356, 1930.

2) G. Schnadez: Uber die Knickung von Platten, Jb. Schiffbt. Ges. 30 (1929), S. 170-194.

3) Th. V. Karman, E. E. Sechler and L. H. Donnell: The Strength of thin plate in Compression, Trans. ASME, 54, 1932, p. 53-56.

4) K. Marguerre: Die Mittragende Breite der gedrückten platte, Lufo., Bd. 14, Nr. 3, 1937.

5）鶴野正敬：平面板の大撓み，壬縮板之之の有勃幅，航 空学会誌, 6 (1939), p. 589-607.

6) H.L. Cox: The Buckling of Thin Plate in Compression, R. \& M., A. R. C.,. No. 1554, 1933.

7) N. J. Hopf : Instability of Monocoque Structures in pure Bending, J. Roy. Aero. Soc., 42, 1938, p. 291-346.

8）吉村度丸：代縮された矩形平板の超安定限界状態の逐 似近似解法, 東大理工研趣告, 2，9 (1949).

9) M. STEIN : NASA TR 39.

10）近藤恭平，林媇：平板の 2 次座屈について，東大理工 研報告, 2, 9 (1949).

11) 植村益次：日本機械学会諭文集， 26 巻 164 号, 30 巻 215 号, 35 巻 276 号.

12) 植村益次, 辺 吾一: 第 13 回構造強度に関する講演 諭文集前刷, 1972 .

13）辺 吾一，植村益次：平板の 1 軸圧縮による 2 次座屈 現象の検討, 日本機械学会, 第 50 期全国大会講演前刷, No. 720-10, 1972.

14）小林繁夫, 浅并自重: 周辺固定矩形板の超高速パネル フラッター限界值, 日本航空宇宙学会誌, 16, 174 (1968), p. 10.

15) S. Kobayasha: Flutter of Simple Supported Rectanguler Panels in a Supersonic Flow., Trans. JAS Vol. 5, No. 8, 1962.

16) W. J. Supple: Int. J. Solid Stru, Vol. 6.

17) 平田隆教, 白沢和大: 有涱要素法による円形アーチの 非線形解析，JSSC，第 7 回大会研究集会論文集，1973， p. 341 .

18) 平田隆教：有限要素法に上る梁及び板の韭線形解析, 日本機械学会論文集, 42 巻 357 号, 1976, p. 1365.

19）平田隆教：はりおよび板殼の座屈安定解析，日本機械 学会誌, 79 巻 691 号, 1976, p. 539. 